Archives of Agriculture and Environmental Science

\title{
Performance of chilli (Capsicum annuum L.) lines with different plantation time during rainy season
}

\author{
M. Ratna ${ }^{1}$, R. Sarker ${ }^{1 *}$ (D) , Rumman Ara ${ }^{2}$, M.M. Hossain ${ }^{3}$ and M.M. Kamruzzaman ${ }^{4,5}$ \\ ${ }^{1}$ Scientific Officer, Regional Horticultural Research Station, BARI, Patuakhali, BANGLADESH \\ ${ }^{2}$ Scientific Officer, Spices Research Sub-centre, BARI, Faridpur, BANGLADESH \\ ${ }^{3}$ Senior Scientific Officer, Regional Spices Research Centre, BARI, Gazipur, BANGLADESH \\ ${ }^{4}$ Scientific Officer, Spices Research Centre, BARI, Bogura, BANGLADESH \\ ${ }^{5}$ Principle Scientific Officer, Spices Research Sub-centre, BARI, Faridpur, BANGLADESH \\ *Corresponding author's E-mail: rumpakbds@gmail.com
}

\section{ARTICLE HISTORY}

Received: 23 July 2018

Revised received: 10 August 2018

Accepted: 18 August 2018

\section{Keywords}

Chili (Capsicum annuum L.)

Chilli lines

Performance

Planting time

Rainy season

\begin{abstract}
The experiment was conducted during April to September, 2016 at Spices Research SubCentre, Faridpur to evaluate the performances of four chilli lines with BARI Morich- 2 as check and to select the suitable planting time during rainy season. The experimental field belongs to high land of Low Ganges River Flood plain (AEZ 12) with clay loam in texture. The experiment was laid out in RCB design with three replications. Four lines and a variety viz., C0711, C0712, C0713 and C0714 and BARI Morich-2 as check were evaluated with three planting time viz., 01 April, 15 April and 30 April. Seedlings of 40 days old were transplanted maintaining of $50 \mathrm{~cm}$ $\times 50 \mathrm{~cm}$ spacing in each case. The crop (Green chilli) was started to harvest from July and completed on August-September, 2016. Among the lines, C0712 emerged as superior in terms of maximum number of fruits/plant (225.7) and weight of fruits/plant (478.6g) and fresh yield $(15.43 \mathrm{t} / \mathrm{ha})$ while the highest single fruit weight $(3.217 \mathrm{~g})$ was found from C0714. The 15 April planting date emerged as best in terms of maximum weighed fruit (2.661g), weight of fruits/ plant (409.3g), number of fruits/plant (182.5) and fresh yield (12.14 t/ha). The interaction effect showed that line C0712 transplanted on 15 April gave the heavier fruits/plants (542.2g) with maximum number of fruits/plant (241.3) and maximum fresh yield (16.73 t/ha). The 15 April planting was ideal for rainy season chilli evaluation and the line C0712 was the most stable performing line with respect to different planting dates.
\end{abstract}

(C)2018 Agriculture and Environmental Science Academy

Citation of this article: Ratna, M., Sarker, R., Ara, R., Hossain, M.M. and Kamruzzaman, M.M. (2018). Performance of chilli (Capsicum annuum L.) lines with different plantation time during rainy season. Archives of Agriculture and Environmental Science, 3(3): 240-244, https://dx.doi.org/10.26832/24566632.2018.030305

\section{INTRODUCTION}

Chili (Capsicum annuum L.) is a spice, a fruit vegetable widely cultivated in the world and which importance in human food is capital (Dias et al., 2013). It is a diploid $(2 n=24)$ species and genetically self-pollinated and chasmogamous crop whose flowers open only after pollination (Lemma, 1998). However, 2 to $96 \%$ out-crossing was observed under open pollination (AVRDC, 2000). Originated from South and Central America, chili, of the genus Capsicum, has more than 25 species of which only five ( $C$. annuum L., C. chinense Jacq.,C. frutescens L., C. baccatum L. and
C. pubescens Keep.) are domesticated and cultivated (Costa et al., 2009). Throughout the world, chili is consumed fresh, dried or in powder (El-Ghoraba et al., 2013). It is rich in proteins, lipids, carbohydrates, fibers, mineral salts ( $\mathrm{Ca}, \mathrm{P}, \mathrm{Fe})$ and in vitamins $\mathrm{A}$, D3, E, C, K, B2 and B12 (El-Ghoraba et al., 2013). The fruits are an excellent source of health-related phytochemical compounds, such as ascorbic acid (vitamin C), carotenoids (provitamin A), tocopherols (vitamin E), flavonoids, and capsaicinoids that are very important in preventing chronic diseases such as cancer, asthma, coughs, sore throats, toothache, diabetes and cardiovascular diseases (Wahyuni et al., 2013). 
Moreover, the consumption of fresh fruits facilitates starchy food digestion (Bhattacharya et al., 2010). Chili has antioxidant, anti-mutagenesis, hypocholesterolemic and immunosuppressive properties (El-Ghoraba et al., 2013) and also inhibits bacterial growth and platelet agglomeration (Wahyuni et al., 2013). At global level, chili is one of the spices that generate huge revenues for producers and therefore contributes to poverty alleviation and improvement of women's social status (Karungi et al., 2013).

Chilli (Capsicum spp. L.) is one of the most popular vegetables, originated from South and Central America (Bahurupe et al., 2013). It is the second most important solanaceous vegetable after tomato grown worldwide both as a spice or vegetable crop (Hasan et al., 2014). Though chilli production is possible throughout the year (Kharif-1, Kharif-2 and Rabi) in Bangladesh, but production is low in Kharif-2 due to some adverse environmental condition. Lack of potential germplasms, water logging condition, high rainfall, high pest and disease incidences etc. These are responsible for low production which leads to high price in that season. A number of local germplasms are cultivated in Faridpur region and meet the largest portion of demand of chilli in Kharif-2. In the varietal developmental process, collection and evaluation of lines/germplasms is a continuous process (Allard, 1960). A journey towards this direction is the selection of better performing chilli lines for cultivating in rainy season. Besides, delayed planting and wrong selection of varieties/ cultivars resulted in inconsistent yield and poor return from chilli cultivation. Optimum sowing time brings about proper growth and development of plants resulting in maximum yield of the crop and economic use of land (Islam et al., 2010). The planting date should therefore be identified in such a way that the crop has the required time for germination, growth, flowering and seeding and appropriate synchronization of flowering with temperatures so that it can use the maximum light and favorable temperatures and produce a high quality yield (Nahardani et al., 2013). However, information regarding the optimum time of planting as well as the interaction effect in combination with chilli lines on the performance of chilli is scanty during rainy season in Faridpur region. Considering the importance of chilli and in view of the above-mentioned facts, the present study was undertaken aiming to identify the suitable chilli line(s) and to find out the optimum planting time of chilli (Capsicum annuum L.) grown for rainy season.

\section{MATERIALS AND METHODS}

The experiment was conducted during April to September, 2016 to evaluate the performances of chilli lines grown in rainy season at three planting time. The experimental field belongs to high land of Low Ganges River Floodplain (AEZ 12) with clay loam in texture having 7.6-8.1 soil $\mathrm{pH}$. Four lines and a variety viz., C0711, C0712, C0713, C0714 and BARI Morich-2 as checkwere evaluated with three planting time viz., 01 April, 15 April and 30 April. The experiment was laid out in RCB design with three replications. The unit plot size was $2.0 \mathrm{~m} \times 1.5 \mathrm{~m}$. Seedlings of 40 days old were transplanted maintaining $50 \mathrm{~cm} \times 50 \mathrm{~cm}$ spacing in each case. The land was fertilized with Cowdung-5 $t$ / ha, $\mathrm{N}_{100}, \mathrm{P}_{66}, \mathrm{~K}_{100}$ and $\mathrm{S}_{20} \mathrm{Kg} / \mathrm{ha}$. Entire quantity of cow dung, $\mathrm{P}$, $1 / 3 \mathrm{~K}$ and $\mathrm{S}$ were applied at the time of final land preparation. $\mathrm{N}$ and $\mathrm{K}$ were applied in three equal splits at 25, 50 and 70 days after transplanting. Five weeding were done at 25, 40, 60, 80 and 100 DAP. To control thrips, tracer @ $0.4 \mathrm{ml} / \mathrm{L}$ of water was sprayed five times. The crop (Green chilli) was started to harvest from July and completed on August-September, 2016. The weather data of Faridpur from April to September 2016 are presented in Tables 1 and 2. Data on yield and yield contributing characters were processed for combined analysis and analyzed statistically using MSTAT computer program.

\section{RESULTS AND DISCUSSION}

\section{Effect of lines}

Means of different yield and yield contributing characters of chilli lines were shown in Table 3 . The tested lines regarding different characters exhibited significant differences except single fruit length. The single fruit weight (3.21g) recorded highest in $\mathrm{C} 0714$ while it was lowest (1.98 g) in BARI Morich-2. The line $\mathrm{C} 0712$ possessed the maximum number of fruits per plant (225.7) followed by C0713 (181.1) while the lowest number of fruits per plant (132.4) was obtained from C0714. The line C0712 gave the highest weight of fruits per plant $(478.6 \mathrm{~g})$ followed by $\mathrm{C} 0713$ (376.3 g) and $\mathrm{C} 0714$ (364.6 g). The highest fresh yield (15.43t/ha) was obtained from C0712 followed by C0714 (11.20 t/ha) and C0713 (11.02 t/ha) while the lowest fresh yield (7.25 t/ha) was obtained from C0711. Mehraj et al. (2014) studied the performance of four chilli lines and found variation on yield among the lines. Padda et al. (1970) observed 113.7 to $399.8 \mathrm{~g}$ fresh weight of fruits per plant of chilli varieties in Punjab. The differential response by different varieties may be due to differences in genetic constituents of the varieties and variable environmental condition (Bergefurd et al., 2011).

\section{Effect of planting time}

A perusal of data presented in Table 4 depicted that different planting dates showed significant effect on the performance of chilli lines. Seedlings transplanted at 15 April emerged as best in terms of maximum weighed fruit (2.66g), weight of fruits/ plant (409.3 g), number of fruits/plant (182.5) and fresh yield (12.14 t/ ha). The increase in yield components with 15 April planting date may be attributed to availability of favorable environmental condition for appropriate synchronization of flowering and subsequent transformation to fruits for producing optimum yield (Nahardani et al., 2013). Reduction in fruit set in delayed planting may be associated with decreased concentrations of reducing sugars in flower buds and flowers that may results failure of pollination and induce abscission of flowers under high temperature condition (Erickson and Markhart, 2001).

\section{Interaction effect}

The result indicated a significant interaction between planting dates and chilli lines in respect of different yield contributing 
attributes (Table 5). The results showed that the line C0712 when transplanting on 15 April gave the maximum number of fruits per plant (241.3) and maximum weight of fruits per plant (542.2g). The lowest number of fruits per plant (122.0) was obtained from $\mathrm{C} 0714$ when transplanted on 01 April. On the other hand the lowest weight of fruits per plant was obtained from C0711 when transplanted in 01 April. The highest fresh yield (16.73 t/ha) was obtained from C0712 when transplanted on 15 April which was identical to $\mathrm{C0712} \times 30$ April but significantly differed from other combinations. Besides, C0713 and C0714 also gave better performance than check in respect of number of fruits per plant (192.7 and 143.7), weight of fruits per plant (429 $\mathrm{g}$ and $386.2 \mathrm{~g}$ ), fresh yield (12.40 t/ha and $12.50 \mathrm{t} / \mathrm{ha}$ ) when transplanting on 15 April.

Table 1. Month wise average temperature, humidity and total rainfall at Faridpur from April to September 2016.

\begin{tabular}{lcccc}
\hline Month & Average maximum $\left({ }^{\circ} \mathrm{C}\right)$ & Average minimum $\left({ }^{\circ} \mathrm{C}\right)$ & Average relative humidity (\%) & Total rainfall (mm) \\
\hline April 2016 & 36.11 & 26.23 & 74.50 & 57.2 \\
May 2016 & 33.22 & 24.71 & 79.80 & 222 \\
June 2016 & 34.08 & 26.22 & 82.73 & 282.2 \\
July 2016 & 32.28 & 26.35 & 88.13 & 497.3 \\
August 2016 & 33.13 & 26.67 & 83.84 & 303.10 \\
September 2016 & 33.31 & 26.36 & 86.03 & 124.7 \\
\hline
\end{tabular}

Table 2. Month wise number of rainfall days and range.

\begin{tabular}{lll}
\hline Month & Number of rainfall days & Range $(\mathrm{mm})$ \\
\hline April 2016 & 3 & $7.8-33$ \\
May 2016 & 14 & $0.9-43.5$ \\
June 2016 & 15 & $0.3-70.6$ \\
July 2016 & 26 & $0.7-90.1$ \\
August 2016 & 20 & $002.2-112.8$ \\
September 2016 & 18 & $000.4-025.4$ \\
\hline
\end{tabular}

Table 3. Yield and yield contributing characters of chilli lines as affected by different lines during 2015-16.

\begin{tabular}{|c|c|c|c|c|c|c|}
\hline Line/variety & $\begin{array}{c}\text { Fruit } \\
\text { length }(\mathrm{cm})\end{array}$ & $\begin{array}{l}\text { Fruit breadth } \\
\text { (cm) }\end{array}$ & $\begin{array}{l}\text { Single fruit } \\
\text { weight (g) }\end{array}$ & $\begin{array}{l}\text { No. of fruits/ } \\
\text { plant }\end{array}$ & $\begin{array}{l}\text { Weight of } \\
\text { fruits/plant (g) }\end{array}$ & $\begin{array}{l}\text { Fresh yield } \\
\text { (t/ha) }\end{array}$ \\
\hline C0711 & $9.35 \mathrm{a}$ & $0.84 b$ & $2.12 \mathrm{~cd}$ & $144.7 d$ & $275.3 d$ & $7.25 \mathrm{~d}$ \\
\hline C0712 & $9.34 \mathrm{a}$ & $0.80 \mathrm{~b}$ & $2.24 \mathrm{c}$ & $225.7 \mathrm{a}$ & $478.6 \mathrm{a}$ & $15.43 \mathrm{a}$ \\
\hline C0713 & $9.52 \mathrm{a}$ & $0.87 a b$ & $2.51 \mathrm{~b}$ & $181.1 \mathrm{~b}$ & $376.3 b$ & $11.02 \mathrm{~b}$ \\
\hline C0714 & $9.85 \mathrm{a}$ & $0.90 \mathrm{a}$ & $3.21 \mathrm{a}$ & $132.4 \mathrm{e}$ & $364.6 \mathrm{bc}$ & $11.20 \mathrm{~b}$ \\
\hline BARI Morich-2 & $9.73 a$ & $0.80 \mathrm{~b}$ & $1.98 \mathrm{~d}$ & $168.1 \mathrm{c}$ & $342.4 c$ & $9.42 \mathrm{c}$ \\
\hline Level of significance & NS & $*$ & $* *$ & $* *$ & $* *$ & $* *$ \\
\hline CV (\%) & 7.25 & 7.76 & 7.86 & 4.97 & 6.65 & 7.79 \\
\hline
\end{tabular}

NS $=$ Non significant, ${ }^{* *}=1 \%$ level of significance; In a column, means followed by the same letter did not differ significantly.

Table 4. Yield and yield contributing characters of chilli lines as affected by different planting times during 2015-16.

\begin{tabular}{lcccccc}
\hline Planting Time & $\begin{array}{c}\text { Fruit length } \\
(\mathrm{cm})\end{array}$ & $\begin{array}{c}\text { Fruit breadth } \\
(\mathrm{cm})\end{array}$ & $\begin{array}{c}\text { Single fruit } \\
\text { weight }(\mathrm{g})\end{array}$ & $\begin{array}{c}\text { Number of } \\
\text { fruits/plant }\end{array}$ & $\begin{array}{c}\text { Weight of } \\
\text { fruits/plant (g) }\end{array}$ & $\begin{array}{c}\text { Fresh yield } \\
(\mathrm{t} / \mathrm{ha})\end{array}$ \\
\hline 01 April & $9.38 \mathrm{a}$ & $0.83 \mathrm{a}$ & $2.21 \mathrm{c}$ & $159.7 \mathrm{c}$ & $331.6 \mathrm{c}$ & $9.77 \mathrm{c}$ \\
15 April & $9.66 \mathrm{a}$ & $0.83 \mathrm{a}$ & $2.66 \mathrm{a}$ & $182.5 \mathrm{a}$ & $409.3 \mathrm{a}$ & $12.14 \mathrm{a}$ \\
30 April & $9.63 \mathrm{a}$ & $0.86 \mathrm{a}$ & $2.38 \mathrm{~b}$ & $169.1 \mathrm{~b}$ & $361.5 \mathrm{~b}$ & $10.68 \mathrm{~b}$ \\
Level of significance & $\mathrm{NS}$ & $*$ & $* *$ & $* *$ & $* *$ & 6.65 \\
CV (\%) & 7.25 & 7.76 & 7.86 & 4.97 & 7.79 \\
\hline
\end{tabular}


Table 5. Inter action effect of line/variety and planting date on different yield attributes of chilliduring 2015-16.

\begin{tabular}{|c|c|c|c|c|c|c|c|}
\hline \multicolumn{2}{|c|}{ Treatments } & \multirow{2}{*}{$\begin{array}{l}\text { Fruit length } \\
\qquad(\mathrm{cm})\end{array}$} & \multirow{2}{*}{$\begin{array}{c}\text { Fruit } \\
\text { breadth }(\mathrm{cm})\end{array}$} & \multirow{2}{*}{$\begin{array}{l}\text { Single fruit } \\
\text { weight }(\mathrm{g})\end{array}$} & \multirow{2}{*}{$\begin{array}{l}\text { Number of } \\
\text { fruits/plant }\end{array}$} & \multirow{2}{*}{$\begin{array}{c}\text { Weight of } \\
\text { fruits/plant (g) }\end{array}$} & \multirow{2}{*}{$\begin{array}{l}\text { Fresh yield } \\
\text { (t/ha) }\end{array}$} \\
\hline Line/Variety & Planting date & & & & & & \\
\hline & 01 April & $9.43 \mathrm{a}$ & $0.87 a-c$ & $1.99 \mathrm{fg}$ & $132.3 \mathrm{fg}$ & $246.9 \mathrm{~h}$ & $6.47 \mathrm{~h}$ \\
\hline \multirow[t]{3}{*}{ C0711 } & 15 April & $9.26 \mathrm{a}$ & $0.78 c$ & $2.35 \mathrm{de}$ & $161.3 \mathrm{e}$ & 310.4 ef & $8.28 \mathrm{fg}$ \\
\hline & 30 April & $9.36 \mathrm{a}$ & $0.86 a-c$ & $2.03 \mathrm{e}-\mathrm{g}$ & $140.3 \mathrm{f}$ & $268.8 \mathrm{gh}$ & $7.00 \mathrm{gh}$ \\
\hline & 01 April & $9.23 \mathrm{a}$ & $0.81 b c$ & $2.04 \mathrm{~d}-\mathrm{g}$ & $214.7 b$ & $434.8 \mathrm{~b}$ & $14.18 b$ \\
\hline \multirow[t]{3}{*}{ C0712 } & 15 April & $9.53 \mathrm{a}$ & $0.83 a-c$ & $2.40 \mathrm{~d}$ & $241.3 a$ & $542.2 \mathrm{a}$ & $16.73 \mathrm{a}$ \\
\hline & 30 April & $9.26 \mathrm{a}$ & $0.78 c$ & $2.28 \mathrm{~d}-\mathrm{f}$ & $221.0 \mathrm{~b}$ & $458.8 \mathrm{~b}$ & $15.37 \mathrm{ab}$ \\
\hline & 01 April & $9.36 a$ & $0.80 \mathrm{bc}$ & $2.26 \mathrm{~d}-\mathrm{f}$ & $169.0 \mathrm{de}$ & 329.3 def & $9.75 d-f$ \\
\hline \multirow[t]{3}{*}{ C0713 } & 15 April & $9.60 \mathrm{a}$ & $0.92 a b$ & $2.87 \mathrm{c}$ & $192.7 \mathrm{c}$ & 429.0 b & $12.40 \mathrm{c}$ \\
\hline & 30 April & $9.60 \mathrm{a}$ & $0.88 a-c$ & $2.40 \mathrm{~d}$ & $181.7 \mathrm{~cd}$ & $370.8 c$ & $10.91 d$ \\
\hline & 01 April & $9.86 a$ & $0.93 a b$ & $3.03 b c$ & $122.0 \mathrm{~g}$ & 346.0 cde & $10.09 \mathrm{de}$ \\
\hline \multirow[t]{3}{*}{ C0714 } & 15 April & $9.66 \mathrm{a}$ & $0.85 a-c$ & $3.38 a$ & $143.7 f$ & $386.2 \mathrm{c}$ & $12.50 \mathrm{c}$ \\
\hline & 30 April & $10.03 a$ & $0.94 a$ & 3.23ab & $131.7 \mathrm{fg}$ & $361.6 \mathrm{~cd}$ & $11.02 \mathrm{~cd}$ \\
\hline & 01 April & 9.03 a & $0.77 c$ & $1.72 \mathrm{~g}$ & $160.3 \mathrm{e}$ & $300.9 \mathrm{fg}$ & $8.38 \mathrm{fg}$ \\
\hline \multirow[t]{2}{*}{ BARI Morich-2 } & 15 April & $10.27 \mathrm{a}$ & $0.80 b c$ & $2.28 \mathrm{~d}-\mathrm{f}$ & $173.3 \mathrm{de}$ & $378.7 c$ & $10.79 d$ \\
\hline & 30 April & $9.90 \mathrm{a}$ & $0.84 a-c$ & $1.95 \mathrm{fg}$ & $170.7 \mathrm{de}$ & 347.4 cde & 9.10 ef \\
\hline \multicolumn{2}{|c|}{ Level of significance } & NS & * & $* *$ & ** & $* *$ & $* *$ \\
\hline \multicolumn{2}{|c|}{ CV (\%) } & 7.25 & 7.76 & 7.86 & 4.97 & 6.65 & 7.79 \\
\hline
\end{tabular}

NS $=$ Non significant, ${ }^{* *}=1 \%$ level of significance; In a column, means followed by the same letter did not differ significantly.

\section{Conclusion}

The findings concluded that 15 April (Fresh yield is $12.14 \mathrm{t} / \mathrm{ha}$ ) was the most suitable time for rainy season chilli evaluation and among the lines C0712 (Fresh yield is $15.43 \mathrm{t} / \mathrm{ha}$ ) was the most stable performing lines with respect to different planting dates. From interaction effect 15 April with line C0712 gave better result (Fresh yield is $16.73 \mathrm{t} / \mathrm{ha}$ ) than others. Besides, C0713 and $\mathrm{C} 0714$ also gave better performance than check in respect of number of fruits per plant, weight of fruits per plant, fresh yield when transplanting on 15 April.

Open Access: This is open access article distributed under the terms of the Creative Commons Attribution License, which permits unrestricted use, distribution, and reproduction in any medium, provided the original author(s) and the source are credited.

\section{REFERENCES}

Allard, R.W. (1960). Principles of Plant Breeding ( $1^{\text {st }}$ Ed). John Wiley and Sons, New York.

AVRDC (2001). AVRDC Report 2000. Asian Vegetable Research and Development Center, Shanhua, Tainan, Taiwan.vii + pp 152.

Bahurupe, J.V., Sakhare, S.B., Kulwal, P.L., Akhare, A.A. and Pawar, B.D. (2013). Genetic diversity analysis in chilli (Capsicum annuum L.) using RAPD markers. An International Quarterly Journal of Life Science, 8 (3): 915-918.

Bergefurd, B.R., Lewis, W., Harker, T., Miller, L., Welch, A. and Weaks, E. (2011). Bell pepper cultivar performance trial grown in southern Ohio. http:// south centers. osu. edu / sites /southc/files/ sitelibrary/ site documents /HORT/ Results/2011/ bellpeppertri-al.pdf.

Bhattacharya, A., Chattopadhyay, A., Mazumdar, D.,
Chakravarty, A. and Pal, S. (2010). Antioxidant constituents and enzyme activities in chilli peppers. International Journal of Vegetable Science, 16: 201-211, https:// doi.org/10.1080/19315260903529709

Costa, L.V., Lopes, R., Lopes, M.T.G., de Figueiedo, A.F., Barros, W.S. and Alves, S.R.M. (2009). Cross compatibility of domesticated hot pepper and cultivated sweet pepper. Crop Breeding and Applied Biotechnology, 9: 37-44

Dias, G.B., Gomes, V.M., Moraes, T.M., Zottich, U.P., Rabelo, G.R., Carvalho, A.O., Moulin, M., Gonçalves, L.S., Rodrigues, R. and Da Cunha, M. (2013). Characterization of Capsicum species using anatomical and molecular data. Genetics and Molecular Research, 12(4): 6488-501, http:// dx.doi.org/10.4238/2013.February.28.29

El-Ghoraba, A.H., Javedb, Q., Anjumb, F.M., Hamedc, S.F., Shaabana, H.A. (2013). Pakistani bell pepper (Capsicum annum L.): Chemical compositions and its antioxidant activity. International Journal of Food Properties, 16(1):18-32.

Erickson, A.N. and Markhart, A.H. (2001). Flower production, fruit set and physiology of bell pepperduringele-vated temperature and vapor pressure deficit. Journal of American Society for Horticultural Science, 126(6): 697-702.

Hasan, M.J., Kulsum, M.U., Ullah, M.Z., Hossain, M.M. and Mahmud, E.M. (2014). Genetic diversity of some chilli (Capsicum annuum L.) genotypes. International Journal of Agricultural Research, Innovation and Technology, 4 (1): 32-35.

Islam, S.M., Akand, S. and Rahim, H. (2010). Effect of sowing date on the growth and yield of sweet pepper (Capsicum annuum L.). Agronomski Glasnik, 1-14.

Karungi, J., Obua, T., Kyamanywa, S., Mortensen, C.N., Erbaugh, M. (2013). Seedling protection and field practices for management of insect vectors and viral diseases of hot pepper (Capsicum chinense Jacq.) in Uganda. International Journal of Pest Management, http:// doi.org/10.1080/09670874.2013.772260 
Lemma D. (1998). Seed production guideline for tomatoes, onion and hot pepper. IAR, Addis Ababa.

Mehraj, H., Tamima, H., Chowdhury, M.S.N., Howlader, M.F. and Jamal Uddin, A.F.M. (2014). Study on mopho-physiological and yield performance of four chilli (Capsicum spp.) lines. Journal of Bioscience and Agricultural Research, 2(1): 01-07.

Nahardani, A.A., Sinaki, J.M., Firouzabadi, M.B. and Abbaspour, H. (2013).Effects of sowing date andbiological fertilizer foliar on yield and yield components of cowpea. International Journal of
Agronomy and Plant Production, 4 (11): 2822-2826.

Padda, D.S., Saimbi, M.S. and Singh, G. (1970). Comparative performance of chilly varieties in Punjab. Punjab Horticulture Journal, 10: 150-154.

Wahyuni, Y., Ballester, A.R., Sudarmonowati, E., Bino R.J. and Bovy A.G. (2013). Secondary metabolites of capsicum species and their importance in the human diet. Journal of Natural Products, 76(4): 783-793, http://doi.org/10.1021/ np300898z 